\title{
Students' Activities in Learning with Problem Based Learning Based Module to Enhance Students' HOTS on the Subject of Straight Line Equations
}

\author{
Imelda $^{1}$, Dewi Anzelina ${ }^{2}$ \\ ${ }^{1,2}$ Universitas Katolik Santo Thomas, Indonesia \\ imelda@ust.ac.id
}

\begin{abstract}
This research begins with the observation of researchers of the activities of students who are still passive when participating in learning in accordance with the 2013 curriculum and do not prioritize students' high order thinking skills. Passive student activities are seen in the core activities of learning because in the core activities students are required to develop existing knowledge in themselves. Thus, the purpose of this study is to produce learning that makes students active. The solution to this problem is the implementation Problem Based Learning (PBL) based module covering Higher Order Thinking Skills (HOTS) questions. The research method used was descriptive qualitative research. The technique used to collect data is a non-test technique, namely the observation sheet of student activities. Observation material consists of 4 aspects, namely observation on preliminary activities, core activities, closing activities and time management. The results obtained are active students during the learning of the subject of straight line equationswith module based on PBL obtained from 7 meetings is $82 \%$, which means that student activities during learning with the problem based learning mathematics learning module on the subject of straight line equations are in the very good category.
\end{abstract}

Keywords: students' activities; module, PBL, HOTS

\section{Introduction}

The 2013 curriculum hopes are still experiencing many obstacles from both teachers and students. The teacher is still accustomed to using learning by explaining in front of the class, giving examples and giving exercises to be done by students. Only the curriculum changed, but the implementation still uses the old curriculum. This makes students confused, because the books and learning resources available are the 2013 curriculum, but the implementation by the teacher is not in accordance with the 2013 curriculum.

The implementation of the 2013 curriculum refers to a scientific approach where learning activities include 5M activities, namely observing, asking, trying, reasoning and communicating. This means that in learning it is hoped that students will be actively involved in the $5 \mathrm{M}$ activities. Based on information obtained from several teachers that starting from the questioning activity.There was no feedback from students. Confused students asking questions will have to be asked. This is one indicator that students are passive in learning activities.

Based on the theory of constructivism, one fundamental principle is that teachers not only provide knowledge to students, but students must also play an active role in building their own knowledge in their memory. In this case, the teacher can make it easy for this process, by giving opportunities to students to find or implement their own ideas, and teach students to be aware and consciously use their own strategies for learning. The teacher can give students steps that take students to a higher level of understanding with their own student notes which they write in their own language and words.

The meaning of learning according to constructivism is an active activity, where students build their own knowledge, look for the meaning of what they are learning and is the process 
of completing new concepts and ideas with the existing and existing framework of thinking (Shymansky, 1992). Constructivism learning theory states that students' cognitive development is obtained through two pathways namely biological processes and psychological processes. (Danoebroto, 2015).

One learning model that embraces constructivism is the problem based learning model. Problem Based Learning (PBL) is learning that focuses on solving problems by students themselves, interpreting and explaining real phenomena and building their understanding of the phenomenon. Problem Based Learning is learning in accordance with the 2013 curriculum. PBL prepares students to think a lot in solving problems in real world life.

The problem in this study is passive students in applying the 2013 curriculum learning. Thus, the purpose of this study is to foster active and meaningful student learning activities for students in solving HOTS questions. Therefore, this research is expected to provide benefits for the creation of a fun and meaningful learning environment. The results of this study also inspired teachers in designing learning modules according to the 2013 curriculum based on PBL to improve students' HOTS.

\section{Review of Literatures}

\subsection{Problem Based Learning}

Weisinger and Arends (in Jailani and Retnawati, H, 2016: 112) explain that one of the recommended learning models in the 2013 curriculum that can be used to improve HOTS is Problem Based Learning (PBL). Problem-based learning is a student-centered learning approach that organizes curriculum and learning in unstructured situations and provides realworld problems.

The syntaxes of PBL-based learning process (Arends in Jailani, Sugiman\&Apino, 2017) are namely: (1) orienting the students toward the problems; (2) organizing the students to learn; (3) guiding the students to perform investigations both individually and collectively; (4) developing and presenting the problem-solving procedure; and analyzing and evaluating the problem-solving process. The PBL learning syntax is used in designing research instruments namely observation sheets of student activities. This means that student activities are carried out in accordance with the PBL syntax that is designed in the module with HOTS problems as problems discussed by students.

\subsection{Higher Order Thinking Skills}

The Australian Council for Educational Research (ACER) (Kemendikbud, 2019: 4) states that high-level thinking skills include the ability to problem solving, critical thinking skills, creative thinking, ability to argue ( reasoning), and the ability to make decisions (decision making). Sulianto, Cintang and Azizah (2018) explained that the ability to think at a higher level involves critical and creative thinking in an effort to determine decisions and solve problems. The ability to think critically consists of the dimensions of the process of analyzing and evaluating, the ability to think creatively consists of the dimensions of the creating process. The ability to think critically and creatively is used to set decisions and solve problems in new situations. The HOTS indicators according to Musfiqi, S and Jailani (2014: 50) are:

1. Identifying and linking data / information relevant to the situation or problem

2. Making the right conclusions from a collection of data / information

3. Assess the quality / accuracy of a statement or argument 
4. Detect consistency and inconsistency in a process / product accompanied by evidence

5. Construct ideas / strategies and use them to solve problems

6. Develop new guesses and alternatives in solving problems.

\subsection{Students' Activities}

Effective learning is learning that provides opportunities for self-study or self-activity. The learning process carried out in class is an activity to transform knowledge, attitudes and skills (MartinisYamin, 2007: 75). Activities are principles or expectations that are very important in teaching and learning interactions (Sardiman, 2006; 96).

Expected learning is when students are able to provide feedback to the teacher. Sardiman (2006: 100) states that learning activities are physical and mental activities. In learning activities, the two are interrelated. Learning activities will be realized if students are actively involved in learning. Martinis Yamin (2007: 82) defines active learning as a human effort to build knowledge within himself. Learning will produce a change and increase the ability, knowledge and skills in students. Students are able to explore their abilities with a curiosity that the interaction that occurs will be the experience and desire to know something new.

Based on some of the opinions above, it can be concluded that learning activities are activities or actions both physical and mental carried out by individuals to build knowledge and skills in themselves in learning activities. Learning activities will make learning more effective.

\section{Research Methods}

This type of research is a qualitative descriptive study. The purpose of this study is to describe student learning activities in using PBL-based learning modules in increasing students' HOTS. This research was conducted at SMP Negeri 4 Binjai Jl. Bejomuna No. 66 Binjai. The subjects of this study were students in SMP Negeri 4 Binjai VIII grade 2019/2020 school year.The object in this study is student learning activities in learning mathematics using PBLbased modules in improving HOTS.The variables in this study are student activities. The students' activities referred to are all activities carried out by students during learning with PBL-based modules to improve HOTS on the materials of Straight Line Equation. The instrument used to assess student activity is the student activity observation sheet.

The research instrument used was a student activity observation sheet. Student activities are classified into two parts, namely active activity and passive activity. Student activities are said to be active if students write that are relevant to learning, discuss and ask questions between students, discuss and ask questions between students and teachers, and read student books or student activity sheets. Student activities are said to be passive if the student does not hear the teacher's explanation, does not hear the explanation of his friend, and does not do anything relevant to learning.

Information on research results is processed through data analysis. Data is processed using the formula:

$$
\text { Percentage }=\frac{\text { Number of Scores Obtained }}{\text { Maximum number of Scores }} \times 100 \%
$$

The decision making criteria for the results of the observation sheets carried out are as follows: 
Table 1. Observation Criteria for Student Activities

\begin{tabular}{|l|l|l|}
\hline No. & Assessment criteria & Criteria \\
\hline 1. & $\mathrm{~A}=81-100$ & Very Well \\
\hline 2. & $\mathrm{~B}=61-80$ & Well \\
\hline 3. & $\mathrm{C}=41-80$ & Enough \\
\hline 4. & $\mathrm{D}=21-40$ & Less \\
\hline 5. & $\mathrm{E}=0-20$ & Very Less \\
\hline
\end{tabular}

\section{Discussion}

Students' activities in this study are all activities and behaviors of students carried out during learning with the PBL module in improving HOTS on the topic of Straight Line Equations lasting seven meetings. Student activities in this study are a series of activities carried out by students during the process of learning problem based learning that has been carried out to improve students' higher order thinking skills. Therefore, all aspects of this observation sheet are PBL learning steps done by students by following the directions and instructions from the teacher. Student activities assessed consist of initial activities, core activities, closing stages and time management.

In the initial stage is feedback on what the teacher does in starting learning with PBL which consists of 4 items. The core activity is the feedback students make towards PBL learning. Student activities observed at the core stage consisted of 14 activities. At the end of the activity phase or closing observing students at the end of learning which consists of 3 activity items. At the time management stage, assesses how students use the study time provided well. Student activity evaluation points consist of a 1-5 rating scale.

Learning activities in this study will be reviewed in two ways including student activities in accordance with PBL steps and student activities according to the scientific approach of $5 \mathrm{M}$ according to the 2013 curriculum.

\subsection{Student Activities According to PBL Syntax}

Learning activities are generally divided into three stages of activities, namely preliminary stages, core activities and closing. Student activities at the preliminary stage obtained can be seen in the following table:

Table 2. Students' Activities in the Preliminary Activities

\begin{tabular}{|c|c|c|c|c|c|c|}
\hline \multirow[t]{2}{*}{ No. } & \multirow[t]{2}{*}{ Observed aspects } & \multicolumn{5}{|c|}{ Assessment } \\
\hline & & 1 & 2 & 3 & 4 & 5 \\
\hline I. & $\begin{array}{l}\text { Preliminary } \\
>\text { Answering greetings and praying } \\
>\text { Lisen to attendance } \\
>\text { Listen to the teacher's explanation } \\
>\text { Form groups }\end{array}$ & & & $\begin{array}{l}1 \\
2\end{array}$ & $\begin{array}{l}4 \\
5 \\
6 \\
6\end{array}$ & 2 \\
\hline & Total & & & 4 & 21 & 3 \\
\hline
\end{tabular}




$$
\begin{aligned}
& \text { Student Activity Value }=\frac{(4 \times 3)+(21 \times 4)+(3 \times 5)}{140} \times 100 \\
& \text { Student Activity Value }=79 \%
\end{aligned}
$$

Based on the results obtained that the activities of students in the preliminary activities carried out as many as 7 meetings on the subject of straight line equations was $79 \%$. Based on the percentage value, the student activities in the preliminary activities are in the good category. After the preliminary activities, the core activities are the next activities. Based on the observations obtained, presented in the following table:

Table 3. Students' Activity in the Core Activities

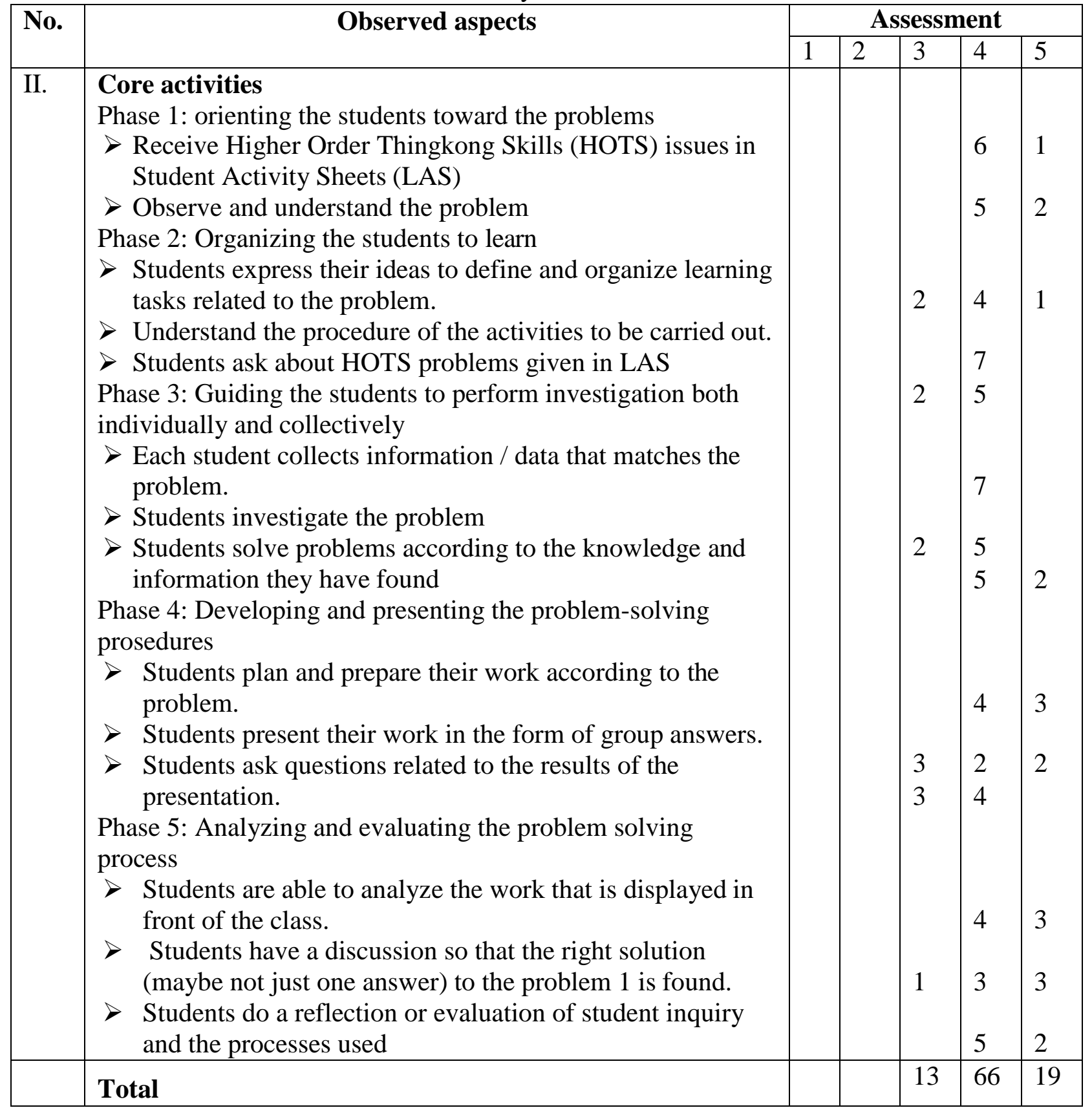




$$
\begin{aligned}
& \text { Student Activity Value }=\frac{(13 \times 3)+(66 \times 4)+(19 \times 5)}{490} \times 100 \\
& \text { Student Activity Value }=81 \%
\end{aligned}
$$

Based on the above results, it is found that student activities in core activities using PBL modules on the subject of straight line equations are worth $81 \%$. Based on this, the student activities in the core activities are in the excellent category.

Activities carried out after the core activities are closing activities and evaluating the use of time by students. The activity was carried out in seven meetings on the subject of straight line equations. An assessment of the closing activities and time usage is presented in the following table:

\begin{tabular}{|c|c|c|c|c|c|c|}
\hline \multirow[t]{2}{*}{ No. } & \multirow[t]{2}{*}{ Observed aspects } & \multicolumn{5}{|c|}{ Assessment } \\
\hline & & 1 & 2 & 3 & 4 & 5 \\
\hline III & $\begin{array}{l}\text { Closing Activity } \\
>\text { Students hear and answer material that is not understood. } \\
>\text { Listen to the teacher's direction. } \\
>\text { Respond to greetings from the teacher. }\end{array}$ & & & 1 & $\begin{array}{l}5 \\
4 \\
4\end{array}$ & $\begin{array}{l}2 \\
2 \\
3\end{array}$ \\
\hline IV & Time management & & & & 5 & 2 \\
\hline & Total & & & 1 & 18 & 9 \\
\hline
\end{tabular}

Table 4. Student Activities in Closing Activities and Time Management

$$
\begin{aligned}
& \text { Student Activity Value }=\frac{(1 \times 3)+(18 \times 4)+(9 \times 5)}{140} \times 100 \\
& \text { Student Activity Value }=86 \%
\end{aligned}
$$

Based on the results of the data analysis above, it was found that the students' activities in the closing activities and the time management carried out on learning using the PBL module in increasing HOTS by 7 meetings for the material of straight-line equations was worth $86 \%$. This percentage value indicates that the student activities carried out in the closing activities and time management are in the very good category.

Overall student activity can be determined by calculating the average of each activity carried out by students, namely preliminary activities, core activities, closing activities and time management. This can be seen in the following table:

Table 5. Students' Activities Using PBL Modules to Enhance Studens' HOTS

\begin{tabular}{|l|l|l|}
\hline No. & Activity & Percentage \\
\hline 1. & Preliminary & 79 \\
\hline 2. & Core activities & 81 \\
\hline 3. & Closing Activity and Time management & 86 \\
\hline & Mean & $\mathbf{8 2}$ (Very Good) \\
\hline
\end{tabular}

The average percentage of students' activity on straight line equation material was $82 \%$. These values indicate that student activities are very good at learning to use the PBL module in increasing students' HOTS. 
4.2. Students' Activities in Accordance with the 2013 Scientific Curriculum Approach Learning by using the PBL module in improving students' HOTS begins when student activities are judged to be still not maximal in learning the 2013 curriculum in the sense that students are still passive even though they are already using the 2013 curriculum. expected by the 2013 curriculum to include $5 \mathrm{M}$ in learning activities. The following is a summary of student activities in learning with the PBL module in increasing students' HOTS which includes 5M activities.

Table 6. Student Activities with Scientific Approaches in the 2013 curriculum

\begin{tabular}{|c|c|c|}
\hline No & Activity & Score \\
\hline 1. & Observe & $(1 \times 3)+(1 \times 4)+(5 \times 5)=32$ \\
\hline 2. & Ask & $(5 \times 4)+(2 \times 5)=30$ \\
\hline 3. & Try & $(3 \times 3)+(4 \times 4)=28$ \\
\hline 4. & Reasoning & $(1 \times 3)+(6 \times 4)=27$ \\
\hline 5. & Communicating & 142 \\
\hline & Total & \\
\hline
\end{tabular}

$$
\begin{aligned}
& \text { Student Activity Value }=\frac{142}{175} \times 100 \\
& \text { Student Activity Value }=81 \%
\end{aligned}
$$

The average percentage of student activity in a scientific approach to $5 \mathrm{M}$ activities with the subject matter of straight-line equations was $81 \%$. This value indicates that student activity is in the very good category. This shows that students are active in learning that is carried out with PBL-based modules in increasing the HOTS of junior high school students.

The results of this study are in line with Jean Piaget's theory of learning and the view of constructivism which explains that students actively construct their own understanding by interacting with their environment through the process of assimilation and accommodation. The interaction that occurs is the interaction of students with students, students with teachers and students with the learning module.

\section{Conclusion}

Students of activities in learning using PBL-based modules in increasing HOTS students are able to bring up active learning activities. The average percentage of student activity in this learning is $82 \%$. This percentage shows that student activity is in the very good category. Thus, it is recommended for teachers to use PBL-based learning modules to improve students' HOTS to create excellent student learning activities so that learning is of higher quality.

\section{Acknowledgment}

Thank you, the authors extend to the Ministry of Research, Technology and Higher Education (Kemenristekdikti) of the Republic of Indonesia for the support and assistance of research funds in the 2019 Academic Year Beginner Lecturer Research scheme that has been provided with agreement letter number T/87/L1.3.1/PT.01.03/2019. Hopefully the results of this study will be useful for the development of Indonesian education science 


\section{References}

A.M. Sardiman, 2006. Interaksi dan Motivasi Belajar Mengajar. Jakarta: PT.Raja Grafindo Persada.

Jailani dan H. Retnawati.2016. Keefektifan Pemanfaatan Perangkat Pembelajaran Berbasis Masalah untuk Meningkatkan HOTS dan Karakter Siswa. Jurnal Pendidikan dan Pembelajaran.

Jailani, J., Sugiman, S., \&Apino, E. 2017. Implementing the problem-based learning in order to improve the students' HOTS and characters. Jurnal Riset Pendidikan Matematika.

Kemendikbud. 2019. Modul Penyusunan Soal Keterampilan Berfikir Tingkat Tinggi (Higher Order Thinking Skills) Matematika. Jakarta: Kemendikbud.

Shymansky, J. (1992). Using Construtivist Ideas to Teach Science Teachers About Constructivist Ideas, or Teachers are Students Tool. Journal Science Teacher Education. S.Musfiqi dan Jailani. (2014). Pengembangan Bahan Ajar Matematika yang Berorientasi pada Karakter dan Higher Order Thinking Skill (HOTS). Pythagoras Jurnal Pendidikan Matematik.

S.W. Dan oebroto. 2015. Teori Belajar Kontruktivis. P4TK Mat., Vol.2. pp. 191-198.

Sulianto, J.Sulianto, N.Cintang dan M.Azizah. (2018). Higher Order Thingking Skills (HOTS) Siswa Pada Mata Pelajaran Matematika di Sekolah Dasar Pilot Project Kurikulum 2013 di Kota Semarang.Universitas PGRI Semarang.

Yamin, Martinis. 2007. Profesionalisasi Guru dan Implementasi KTSP. Jakarta: Gaung Persada Press. 